\title{
Steroid responsive encephalopathy in cerebral amyloid angiopathy: a case report and review of evidence for immunosuppressive treatment
}

\author{
Raoul P Kloppenborg ${ }^{1}$, Edo Richard ${ }^{1}$, Marieke ES Sprengers ${ }^{2}$, Dirk Troost ${ }^{3}$, Piet Eikelenboom, Paul J Nederkoorn ${ }^{1 *}$
}

\begin{abstract}
Cerebral amyloid angiopathy (CAA) is a common but often asymptomatic disease, characterized by deposition of amyloid in cerebral blood vessels. We describe the successful treatment of CAA encephalopathy with dexamethasone in a patient with CAA-related inflammation causing subacute progressive encephalopathy and seizures, which is an increasingly recognized subtype of CAA. The two pathological subtypes of CAA-related inflammation are described and a review of the literature is performed concerning immunosuppressive treatment of CAA-related inflammation with special attention to its pathological subtypes. Immunosuppressive therapy appears to be an appropriate treatment for CAA encephalopathy.
\end{abstract}

\section{Background}

Sporadic cerebral amyloid angiopathy (CAA) is a common but often asymptomatic neuropathological finding, characterized by the deposition of amyloid- $\beta(A \beta)$ in small and medium-sized cerebral arteries, arterioles and sometimes capillaries of the meninges and brain parenchyma. Its prevalence is strongly associated with increasing age and has been reported to be as high as $57 \%$ percent in case series of asymptomatic patients over 60 years of age [1]. CAA is a common finding in patients with Alzheimer's disease $(\mathrm{AD})$; but many patients with CAA do not develop AD. CAA can lead to lobar haemorrhage in non-hypertensive patients [2]. Other, less often reported clinical manifestations are seizures, transient neurological deficits and dementia other than AD [3]. In addition, more rare presentations have been reported, including space occupying lesions and leukoencephalopathy on magnetic resonance imaging (MRI) [4-6]. The latter is an increasingly recognized syndrome encompassing subacute encephalopathy, headache, seizures or focal neurological symptoms. Upon brain biopsy, an inflammatory process is found in relation to the vascular deposits of $A \beta$. In contrast to other $A \beta$-depositing disorders such as $\mathrm{AD}$, immunosuppressive treatment has been reported to

\footnotetext{
* Correspondence: p.j.nederkoorn@amc.uva.nl

${ }^{1}$ Department of Neurology, Academic Medical Center, Amsterdam, The
} Netherlands ameliorate both clinical and radiological symptoms of CAA encephalopathy, although with variable success [7]. This variability could be explained by the existence of different underlying pathological subtypes. We describe a patient with CAA-leukoencephalopathy, who was treated successfully with dexamethasone. We also performed a literature review concerning the use of immunosuppressive treatment for CAA-related inflammation with special attention to its pathological subtypes.

\section{Case presentation}

A 74-year-old man with an unremarkable medical history noted a progressive gait disorder in the months prior to admission. His wife recalled increased sleepiness and loss of initiative. After having seizures the patient was admitted to our hospital. The patient was disorientated in time and did not perform complicated tasks, although this could partly be attributed to apathy. $\mathrm{He}$ could not remember the reason for his stay in the hospital. The remaining neurological examination revealed no abnormalities. MRI showed confluent bifrontal white matter lesions and minimal enhancement of the white matter in the right frontal lobe after administration of gadolinium (Figure 1A-D). Routine laboratory measurements were normal. Cerebral spinal fluid examination revealed an elevated protein level $(1.78 \mathrm{~g} / \mathrm{l})$. No malignant cells were found in the spinal fluid. After diagnostic work-up had excluded a primary tumour elsewhere 

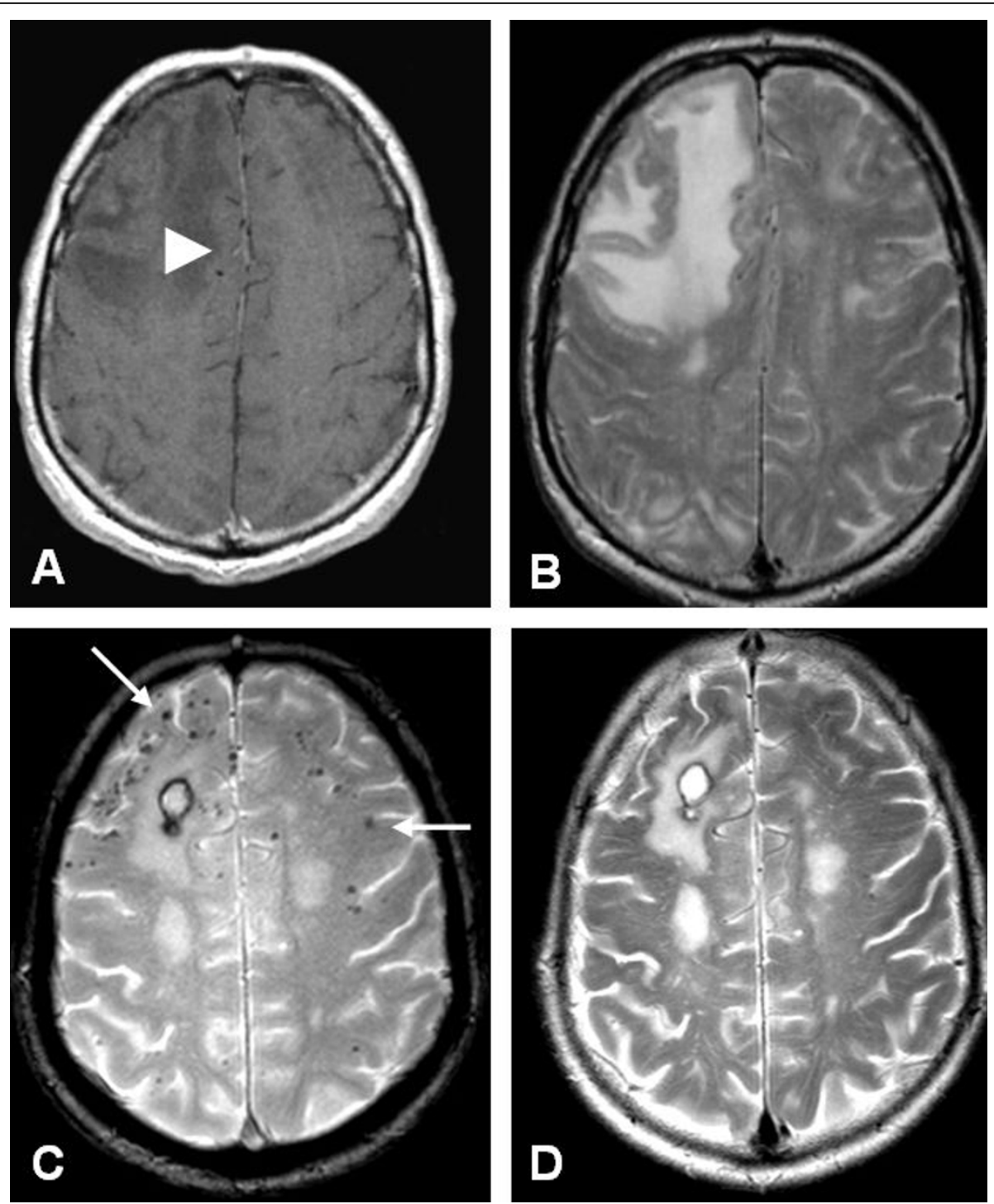

Figure 1 Axial MRI at presentation (A, B) and 3 months after treatment (C, D). A) Contrast enhanced, T1- weighted image shows low signal intensity of the right frontal lobe with minimal enhancement of the white matter (white arrowhead). B) T2-weighted image shows high signal intensity in the right frontal lobe. C) Gradient echo sequence shows subcortical 'black dots', consistent with microbleeds (white arrows), and a small postoperative hematoma after biopsy. D) T2-weighted image after treatment shows a decrease of high signal intensity in the right frontal lobe.

in the body, low grade astrocytoma or gliomatosis cerebri was considered and a stereotactic brain biopsy was performed. Histopathological analysis showed extensive $\mathrm{A} \beta$ immunopositivity around smaller and larger blood vessels (Figure 2A, B). No neurofibrillary tangles or amyloid plaques were found in the parenchyma. Reactive gliosis, strong upregulation of microglia and multiple macrophages around the blood vessels in both white and grey matter were present (Figure 2C, D). The findings were compatible with sporadic CAA. After the patient developed progressive apathy, loss of initiative, magnetic gait and hypertonia of the extremities, treatment with dexamethasone $(2 \times 4 \mathrm{mg} /$ day $)$ was started. There was a remarkable clinical improvement in the following days. The patient became alert, the hypertonia disappeared and he was able to walk with a wheeled walker. After 5 weeks, he was discharged from the hospital with a mild gait disorder. A 3 Tesla MRI three months after admission showed remarkable amelioration of the white matter abnormalities. Gradient echo sequences showed subcortical hypointensities, compatible with multiple microbleeds (figure 1). Dexamethasone treatment was tapered in the months after admission. 


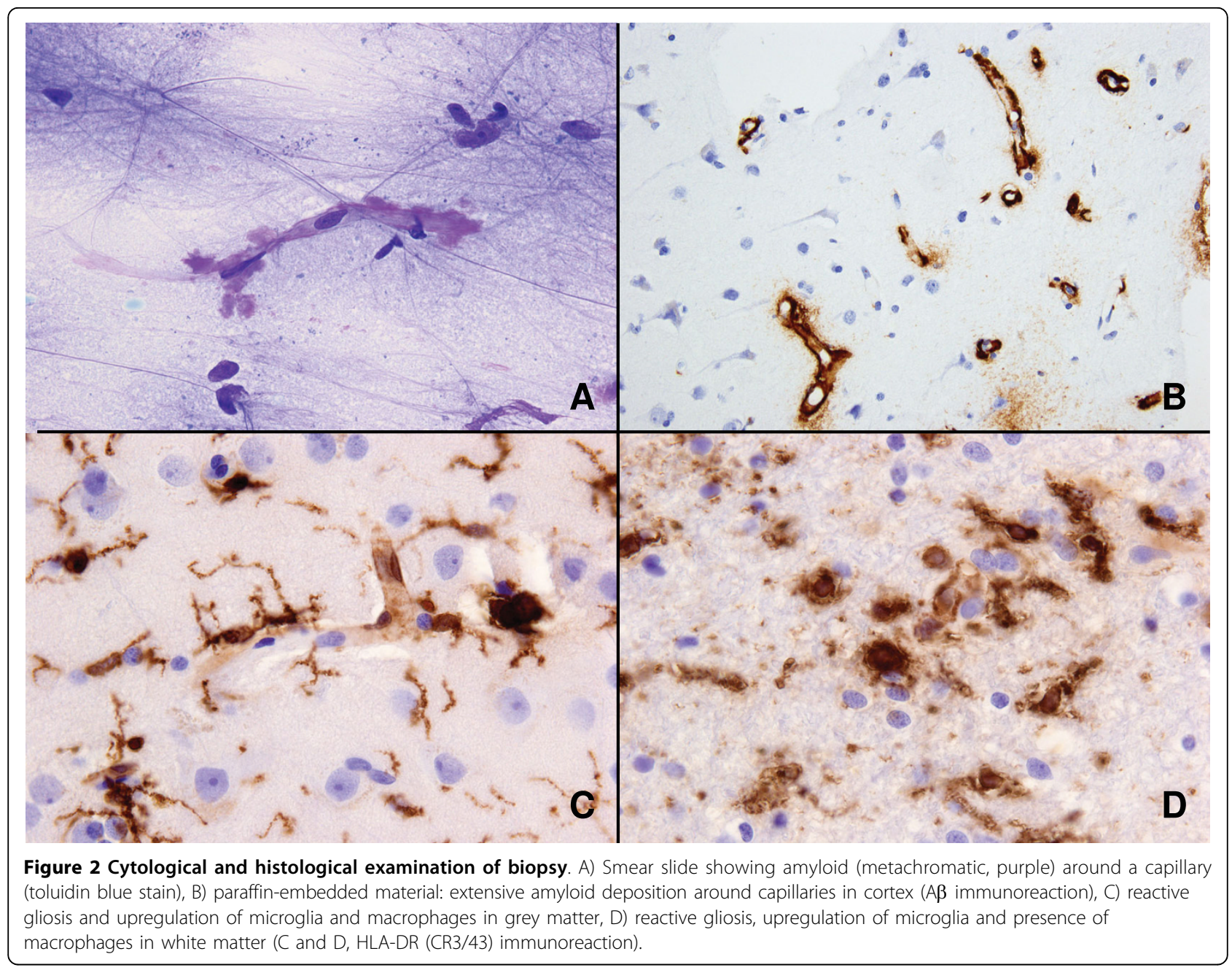

\section{Discussion}

The clinical picture of CAA-related inflammation includes encephalopathy, seizures and headaches. Extensive vasogenic edema and/or leukoencephalopathy is visible on MRI, sometimes mimicking space-occupying lesions. Histological examination shows amyloid-laden vessels and the appearance of $\mathrm{A} \beta$ in close association with inflammatory cells, implicating $A \beta$ as the potential trigger for the inflammatory response. It remains unclear why only a few CAA patients develop this response. A high percentage of such patients are homozygous for the 84 -allele of the apolipoprotein E gene (APOE $\varepsilon 4 / \varepsilon 4 ; 76.9 \%$ vs $5.1 \%$ in noninflammatory CAA) [6], which is associated with activation of complement and microglia. Additionally, trials of anti$A \beta$ vaccination in patients with Alzheimer's disease (AD) induced similar clinical, radiological and pathological inflammation as seen in CAA-related inflammation, suggesting an immune response to $A \beta$.

Unlike other $A \beta$-depositing disorders, CAA-associated inflammation appears to derive a beneficial effect from corticosteroid treatment. This effect could be dependant on the pathological subtype of CAA-related inflammation.

Two subtypes of CAA-associated inflammation have been described so far: (i) a non-vasculitic form called perivascular infiltration (PVI), which is characterized by perivascular infiltration of the parenchyma by multinucleated giant cells and (ii) a vasculitic form called transmural (non)-granulomatous angiitis (TGA), which is characterized by inflammation of the vessel wall with the occasional presence of granulomas. Both pathologic forms can co-occur, suggesting at least a partial overlap [8]. The clinical and radiological findings of both variants are remarkably similar. Our case showed reactive gliosis and multiple macrophages around blood vessels in grey and white matter, although no multinucleated cells were seen. This is consistent with reactive edema in encephalopathy and suggests PVI. Although often called CAA-angiitis, the terms CAA-vasculopathy or CAA-encephalopathy are preferred, since these terms do 
Table 1 Studies concerning immunosuppresive treatment of CAA encephalopathy

\begin{tabular}{|c|c|c|c|c|c|c|c|c|c|c|}
\hline Author & $\mathrm{n}$ & Age & Pathology & Radiology & Therapy & $\begin{array}{l}\text { Clinical } \\
\text { improvement }\end{array}$ & $\begin{array}{l}\text { Radiological } \\
\text { improvement }\end{array}$ & $\begin{array}{l}\text { Follow- } \\
\text { up }\end{array}$ & $\begin{array}{l}\text { Clinical } \\
\text { features }\end{array}$ & Comments \\
\hline $\begin{array}{l}\text { Ginsberg } 1988 \\
{[10]}\end{array}$ & 1 & 73 & TGA & Confluent & $\mathrm{Dx}, \mathrm{Pn}$ & Yes & Yes & $>1$ year & Gait disturbance & \\
\hline $\begin{array}{l}\text { Mandybur } 1992 \\
\text { [11] }\end{array}$ & 1 & 62 & TGA & Mass & $C P, P n$ & Yes & Yes & $\begin{array}{l}\text { Death } 8 \\
\text { months }\end{array}$ & $\begin{array}{l}\text { Encephalopathy } \\
\text { Focal neurology } \\
\text { Hallucinations }\end{array}$ & $\begin{array}{l}\text { Remarkable } \\
\text { pathological } \\
\text { improvement lesions } \\
\text { post-mortem } \\
\text { compared to initial } \\
\text { biopsy }\end{array}$ \\
\hline Osumi 1995 [4] & 1 & 59 & $?$ & Mass & CS & No & $?$ & $\begin{array}{l}\text { Death } 5 \\
\text { months }\end{array}$ & $\begin{array}{l}\text { Focal neurology } \\
\text { Headaches } \\
\text { Seizures }\end{array}$ & \\
\hline Silbert 1995 [12] & 1 & 74 & $?$ & Confluent & $D x$ & No & No & $\begin{array}{l}\text { Death } 6 \\
\text { weeks }\end{array}$ & $\begin{array}{l}\text { Headache } \\
\text { Seizures }\end{array}$ & \\
\hline $\begin{array}{l}\text { Fountain } 1996 \\
\text { [13] }\end{array}$ & 1 & 66 & TGA & Confluent & $\begin{array}{l}C P, D x \\
P n\end{array}$ & No & Partial & $\begin{array}{l}20 \\
\text { months }\end{array}$ & $\begin{array}{l}\text { Encephalopathy } \\
\text { Headaches } \\
\text { Seizures }\end{array}$ & \\
\hline $\begin{array}{l}\text { Fountain } 1996 \\
\text { [13] }\end{array}$ & 1 & 69 & TGA & Confluent & $\begin{array}{l}C P, D x \\
P n\end{array}$ & Partial & Partial & $\begin{array}{l}\text { Death } 6 \\
\text { months }\end{array}$ & $\begin{array}{l}\text { Encephalopathy } \\
\text { Headaches } \\
\text { Seizures }\end{array}$ & Relapse \\
\hline Ortiz 1996 [14] & 1 & 68 & $\mathrm{PVI}$ & Mass & $\mathrm{Dx}, \mathrm{Pn}$ & Yes & Yes & $?$ & $\begin{array}{l}\text { Encephalopathy } \\
\text { Gait disturbance } \\
\text { Headaches }\end{array}$ & \\
\hline $\begin{array}{l}\text { Masson } 1998 \\
{[15]}\end{array}$ & 1 & 64 & $\mathrm{PVI}$ & Confluent & $C P, P n$ & Yes & No & $\begin{array}{l}15 \\
\text { months }\end{array}$ & $\begin{array}{l}\text { Encephalopathy } \\
\text { Headaches }\end{array}$ & \\
\hline $\begin{array}{l}\text { Fountain } 1999 \\
\text { [16] }\end{array}$ & 1 & 71 & PVI, TGA & Confluent & $\mathrm{CP}$ & Yes & Yes & $\begin{array}{l}22 \\
\text { months }\end{array}$ & $\begin{array}{l}\text { Encephalopathy } \\
\text { Gait disturbance } \\
\text { Headaches }\end{array}$ & Relapse after stop CP \\
\hline $\begin{array}{l}\text { Streichenberger } \\
1999[17]\end{array}$ & 1 & 67 & TGA & $\begin{array}{l}\text { Mass/ } \\
\text { Confluent }\end{array}$ & CS & Yes & Yes & $\begin{array}{l}\text { Death } 1 \\
\text { month }\end{array}$ & $\begin{array}{l}\text { Headaches } \\
\text { Encephalopathy }\end{array}$ & \\
\hline Hoshi 2000 [18] & 1 & 65 & $\begin{array}{l}\text { - (after } \\
\text { treatment) }\end{array}$ & $\begin{array}{l}\text { Recurrent } \\
\mathrm{ICH}\end{array}$ & $\mathrm{Pn}$ & Yes & NA & $\begin{array}{l}6 \\
\text { months }\end{array}$ & Focal neurology & \\
\hline $\begin{array}{l}\text { Schwab } 2003 \\
\text { [19] }\end{array}$ & 1 & 74 & $\mathrm{PVI} / \mathrm{TGA}$ & Mass & $\begin{array}{l}\text { Dx 1m, } \\
\text { Pn }\end{array}$ & Yes & $?$ & $\begin{array}{l}12 \\
\text { months }\end{array}$ & $\begin{array}{l}\text { Encephalopathy } \\
\text { Headaches } \\
\text { Seizures }\end{array}$ & \\
\hline $\begin{array}{l}\text { Schwab } 2003 \\
\text { [19] }\end{array}$ & 1 & 70 & $\mathrm{PVI} / / \mathrm{TGA}$ & Mass & $\mathrm{Pn}, \mathrm{CP}$ & Partial & Yes & $\begin{array}{l}18 \\
\text { months }\end{array}$ & $\begin{array}{l}\text { Encephalopathy } \\
\text { Headaches } \\
\text { Seizures }\end{array}$ & \\
\hline Oh 2004 [20] & 1 & 80 & $\mathrm{PVI}$ & Confluent & $\mathrm{Dx}, \mathrm{Pn}$ & Yes & Yes & $\begin{array}{l}8 \\
\text { months }\end{array}$ & $\begin{array}{l}\text { Encephalopathy } \\
\text { Focal Neurology } \\
\text { Seizures }\end{array}$ & $\begin{array}{l}1 \text { patient with no } \\
\text { therapy excluded }\end{array}$ \\
\hline Oh 2004 [20] & 1 & 77 & TGA & Confluent & $\mathrm{Dx}, \mathrm{Pn}$ & Yes & Yes & 6 weeks & $\begin{array}{l}\text { Encephalopathy } \\
\text { Focal Neurology } \\
\text { Seizures }\end{array}$ & $\begin{array}{l}1 \text { patient with no } \\
\text { therapy excluded }\end{array}$ \\
\hline Safriel 2004 [5] & 1 & 49 & TGA & Mass & $\begin{array}{l}\text { Dx, tap } \\
6 \text { weeks }\end{array}$ & Yes & Partial & $\begin{array}{l}9 \\
\text { months }\end{array}$ & Seizures & \\
\hline $\begin{array}{l}\text { Scolding } 2005 \\
{[21]}\end{array}$ & 7 & $69^{*}$ & TGA & Confluent & $\begin{array}{l}P n, D x \\
C P\end{array}$ & $43 \%$ & $?$ & $\begin{array}{l}58 \\
\text { months* }\end{array}$ & $\begin{array}{l}\text { Encephalopathy } \\
\text { Focal Neurology } \\
\text { Headaches } \\
\text { Seizures }\end{array}$ & $\begin{array}{l}2 \text { patients excluded } \\
\text { because of mass } \\
\text { resection as therapy }\end{array}$ \\
\hline $\begin{array}{l}\text { Kinnecom } 2007 \\
\text { [6] }\end{array}$ & 12 & $\begin{array}{l}63.2 \\
\pm 10\end{array}$ & $\mathrm{PVI}$ & Confluent & $C S, C P$ & $83 \%$ & $83 \%$ & $\begin{array}{l}47 \\
\text { months* }\end{array}$ & $\begin{array}{l}\text { Encephalopathy } \\
\text { Headache } \\
\text { Seizures }\end{array}$ & $25 \%$ relapse, $33 \%$ died \\
\hline $\begin{array}{l}\text { McHugh } 2007 \\
\text { [9] }\end{array}$ & 1 & 80 & PVI, TGA & Confluent & $P n$ & Yes & Yes & $\begin{array}{l}24 \\
\text { months }\end{array}$ & $\begin{array}{l}\text { Encephalopathy } \\
\text { Focal Neurology } \\
\text { Seizures }\end{array}$ & \\
\hline $\begin{array}{l}\text { Machida } 2008 \\
\text { [22] }\end{array}$ & 1 & 69 & $\mathrm{PVI}$ & Confluent & $D x, P n$ & Yes & Yes & $\begin{array}{l}12 \\
\text { months }\end{array}$ & $\begin{array}{l}\text { Encephalopathy } \\
\text { Focal neurology }\end{array}$ & Relapsing/remitting \\
\hline
\end{tabular}


Table 1: Studies concerning immunosuppresive treatment of CAA encephalopathy (Continued)

\begin{tabular}{|c|c|c|c|c|c|c|c|c|c|c|}
\hline $\begin{array}{l}\text { Salvarini } 2008 \\
\text { [23] }\end{array}$ & 8 & 63 & TGA & Confluent & $P n, C P$ & $75 \%$ & $100 \%$ & $\begin{array}{l}24 \\
\text { months* }\end{array}$ & $\begin{array}{l}\text { Encephalopathy } \\
\text { Focal Neurology } \\
\text { Headaches }\end{array}$ & $\begin{array}{l}25 \% \text { relapse, both } \\
\text { after discontinuation } \\
\text { of treatment }\end{array}$ \\
\hline
\end{tabular}

$\mathrm{CS}=$ corticosteroid (not otherwise specified), $\mathrm{CP}=$ Cyclophospamid, $\mathrm{Dx}=$ dexamethasone, $\mathrm{Pn}=$ prednisone, $\mathrm{PVI}=$ perivascular inflammation, $\mathrm{TGA}=$ transmural (non)-granulomatous angiitis

Encephalopathy is characterised as diffuse cognitive disturbances, somnolence and apathy, focal neurology is characterised as hemiparesis, hemihyesthesia, aphasia or hemianopsy.

* calculated mean

not exclude the considerable numbers of cases with only perivascular inflammation [8].

Because of various reports regarding success of corticosteroid treatment, we performed a literature review on the use of immunosuppressive agents in CAA-encephalopathy with special attention to its pathological subtypes. A total of 45 patients in 18 articles could be identified (Table 1) [4-6,8-22]. In four patients TGI and PVI co-occurred $[8,15,18]$. Corticosteroids were the most commonly used drugs, varying from short, highdosage intravenous treatments to continuous treatment with low-dose prednisone. One case report reported effective treatment with low dose cyclophosmamid alone [16]. Similar to our case, there were generally favourable outcomes in most patients after immunosuppressive treatment. Clinical and radiological symptoms were (partly) reversed in $76 \%$ of all patients, although some experienced relapses during follow-up.

Although publication bias, small study numbers and the possible self-limiting nature of the disease has to be taken into account, the quick response to immunosuppressive therapy and the tendency to relapse in drugfree periods suggest a beneficial effect of immunosuppressants. In general, patients with TGA did not benefit as much as patients with PVI [68\% vs $88 \%$ ]: possibly the vasculitic form gives rise to more ischemic lesions (reflected in the higher proportion of focal deficits in this group) than in PVI, in which there could be more vasogenic edema.

It is interesting that only CAA encephalopathy responds to corticosteroid treatment, in contrast to other $A \beta$-depositing disorders. A possible explanation could be that corticosteroids merely reduce cerebral vasogenic edema. However, in vitro research has shown that dexamethasone diminishes the pro-inflammatory and cytotoxic effects of $A \beta$ in cerebrovascular smooth muscle cells in later stages of the inflammation process, although it does not affect initial $\mathrm{A} \beta$ deposition [23]. This suggests a direct effect upon the pathogenesis of acute inflammation in $A \beta$-disorders, as it is found in CAA encephalopathy. In any case, our review shows there is a possible role for the use of corticosteroids in patients with CAA encephalopathy.

\section{Conclusions}

CAA encephalopathy is an increasingly recognized syndrome that is based upon a vasculitic or non-vasculitic inflammatory reaction to $A \beta$. Although the clinical and radiological symptoms are similar in both pathologic variants, immunosuppressive therapy appears to have a slightly less beneficial effect in the vasculitic subtype. Nevertheless, corticosteroid therapy seems to be an appropriate therapy for both. In an elderly patient with a subacute progressive encephalopathy with seizures, CAA-related encephalopathy has to be considered because of the major therapeutical implications.

\section{Consent}

Written informed consent was obtained from the next of kin of the patient for publication of this case report and accompanying images. A copy of the written consent is available for review by the Editor-in-Chief of this journal.

\section{Author details \\ ${ }^{1}$ Department of Neurology, Academic Medical Center, Amsterdam, The Netherlands. '2Department of Radiology, Academic Medical Center, Amsterdam, The Netherlands. ${ }^{3}$ Department of Neuropathology, Academic Medical Center, Amsterdam, The Netherlands.}

\section{Authors' contributions}

RPK participated in the design of the article, collected and analyzed the data and drafted the manuscript. ER, PE and PJN contributed to the analysis and interpretation of the data. MES and DT provided radiological and pathological data respectively. PJN conceived of the case report and coordinated the drafting of the manuscript. All authors read and approved the final manuscript.

\section{Competing interests}

The authors declare that they have no competing interests.

Received: 8 January 2010 Accepted: 9 March 2010

Published: 9 March 2010

\section{References}

1. Yamada M, Tsukagoshi H, Otomo E, Hayakawa M: Cerebral amyloid angiopathy in the aged. J Neurol 1987, 234:371-6.

2. Gilbert JJ, Vinters HV: Cerebral amyloid angiopathy: incidence and complications in the aging brain. I. Cerebral hemorrhage. Stroke 1983, 14:915-23.

3. Greenberg SM, Vonsattel JPG, Stakes JW, Gruber M, Finklestein SP: The clinical spectrum of cerebral amyloid angiopathy: Presentations without lobar hemorrhage. Neurology 1993, 43:2073-2079. 
4. Osumi KA, Tien RD, Felsberg GJ, Rosenbloom M: Cerebral amyloid angiopathy presenting as a brain mass. Am J Neuroradiol 1995, 16:911-915

5. Safriel $Y$, Sze G, Westmark K, Baehring J: MR spectroscopy in the diagnosis of cerebral amyloid angiopathy presenting as a brain tumor. Am J Neuroradiol 2004, 25:1705-8.

6. Kinnecom C, Lev MH, Wendell L, Smith EE, Rosand J, Frosch MP, Greenberg SM: Course of cerebral amyloid angiopathy-related inflammation. Neurology 2007, 68:1411-6.

7. Aisen PS: The potential of anti-inflammatory drugs for the treatment of Alzheimer's disease. Lancet Neurol 2002, 1:279-84.

8. McHugh JC, Ryan AM, Lynch T, Dempsey E, Stack J, Farrell MA, Kelly PJ: Steroid-responsive recurrent encephalopathy in a patient with cerebral amyloid angiopathy. Cerebrovasc Dis 2007, 23:66-9.

9. Ginsberg L, Geddes J, Valentine A: Amyloid angiopathy and granulomatous angiitis of the central nervous system: a case responding to corticosteroid treatment. J Neurol 1988, 235:438-40.

10. Mandybur TI, Balko G: Cerebral amyloid angiopathy with granulomatous angiitis ameliorated by steroid-cytoxan treatment. Clin Neuropharmacol 1992, 15:241-7.

11. Silbert PL, Bartleson JD, Miller GM, Parisi JE, Goldman MS, Meyer FB: Cortical petechial hemorrhage, leukoencephalopathy, and subacute dementia associated with seizures due to cerebral amyloid angiopathy. Mayo Clin Proc 1995, 70:477-80

12. Fountain NB, Eberhard DA: Primary angiitis of the central nervous system associated with cerebral amyloid angiopathy: Report of two cases and review of the literature. Neurology 1996, 46:190-197.

13. Ortiz O, Reed $\mathrm{L}$ : Cerebral amyloid angiopathy presenting as a nonhemorrhagic, infiltrating mass. Neuroradiology 1996, 38:449-52.

14. Masson C, Hénin D, Colombani JM, Dehen H: A case of cerebral giant-cell angiitis associated with cerebral amyloid angiopathy. Favorable evolution with corticosteroid therapy. Rev Neurol (Paris) 1998, 154:695-8.

15. Fountain NB, Lopes MB: Control of primary angiitis of the CNS associated with cerebral amyloid angiopathy by cyclophosphamide alone. Neurology 1999, 52:660-2.

16. Streichenberger N, Girard-Madoux P, Verejan I, Pialat J, Vital C, Kopp N: Giant cell angiitis of the central nervous system with amyloid angiopathy. A case report and review of the literature. Clin Exp Pathol 1999, 47:311-7.

17. Hoshi K, Yoshida K, Nakamura A, Tada T, Tamaoka A, Ikeda S: Cessation of cerebral hemorrhage recurrence associated with corticosteroid treatment in a patient with cerebral amyloid angiopathy. Amyloid 2000, 7:284-8.

18. Schwab P, Lidov HGW, Schwartz RB, Anderson RJ: Cerebral amyloid angiopathy associated with primary angiitis of the central nervous system: report of 2 cases and review of the literature. Arthr Reum 2003, 49:421-427.

19. Oh U, Gupta R, Krakauer JW, Khandji AG, Chin SS, Elkind MS: Reversible leukoencephalopathy associated with cerebral amyloid angiopathy. Neurology 2004, 62:494-7.

20. Scolding NJ, Joseph F, Kirby PA, Mazanti I, Gray F, Mikol J, Ellison D, Hilton DA, Williams TL, MacKenzie JM, Xuereb JH, Love S: A $\beta$-relAted angiitis: primary angiitis of the central nervous system associated with cerebral amyloid angiopathy. Brain 2005, 128:500-15.

21. Machida K, Tojo K, Naito KS, Gono T, Nakata Y, Ikeda S: Cortical petechial hemorrhage, subarachnoid hemorrhage and corticosteroid-responsive leukoencephalopathy in a patient with cerebral amyloid angiopathy. Amyloid 2008, 15:60-4.

22. Salvarani C, Brown RD Jr, Calamia KT, Christianson TJ, Huston J, Meschia JF, Giannini C, Miller DV, Hunder GG: Primary central nervous system vasculitis: comparison of patients with and without cerebral amyloid angiopathy. Rheumatology 2008, 47:1671-7.

23. Previti ML, Zhang W, van Nostrand WE: Dexamethason diminishes the pro-inflammatory and cytotoxic effects of $\beta$-protein in cerebrovascular smooth muscle cells. J Neuroinflammation 2006, 3:18.

doi:10.1186/1742-2094-7-18

Cite this article as: Kloppenborg et al.: Steroid responsive encephalopathy in cerebral amyloid angiopathy: a case report and review of evidence for immunosuppressive treatment. Journal of Neuroinflammation 2010 7:18.

\section{Submit your next manuscript to BioMed Central and take full advantage of:}

- Convenient online submission

- Thorough peer review

- No space constraints or color figure charges

- Immediate publication on acceptance

- Inclusion in PubMed, CAS, Scopus and Google Scholar

- Research which is freely available for redistribution 